\title{
新発見の毒鳥ニューギニアピトフイをめぐって
}

\section{富士川 龍郎}

和泉 堯己 比治山大学

生物は自己防衛や他の動物を捕食するために，しばし ば体内に毒を生産したり, 食物中の毒を蓄積したりして いる.へビやサソリの毒は前者の例であるし，フグ毒な どは後者の典型例であろう。しかし，このような毒は， 伝説は別として，鳥類ではこれまで聞かれなかった．と

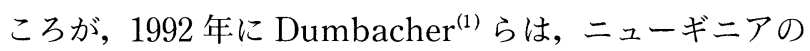
密林に猛毒をもつ鳥 “ニューギニアピトフイ”を確認し た。この鳥はテレビに登場したこともあるのでご記憶の 方も多いであろう。

一方，伝説的な毒鳥となると，中国に有名な“䳋”（ち ん）という鳥がいて，これが上記のニューギニアピトフ イといくらか共通するところがあり，ひょっとすると同 一の，ないしは近縁の鳥である可能性も考えられた。 そ こで，ニューギニアピトフイとその毒の紹介をかねて， その辺りの事情を述べ, 後を好学の方に任せたいと考え て筆を取った次第である。

\section{マニューギニアピトフイとは？}

まず，“毒鳥ニューギニアピトフイ”とはどんな鳥かと いうことを Dumbacher らの報文 ${ }^{(1)}$ から紹介しよう。こ の報文では 3 種扱われているが，ここでは毒性の最も強 いフードピトフイ hooded pitohui (Pitohui dichrous) を代表例として述べる。なお，この鳥は和名が未定のよ うなので，仮にカタカナ表記にしておく、フードピトフ イを同誌のカラー写真からスケッチしたものを図 1 に示 す.

フードピトフイは冠毛をもち，外観は後頭部を残して 頭から胸にかけて，また翼と尾羽が黒，残りの部分は茶 橙色 (むしろ黒身に茶橙色のチョッキを着せたよう)で, かなり目立つ色彩である。重さは成鳥で 60〜 $70 \mathrm{~g} く ら$ い, 写真からはなかなか精悍な感じを受ける.ピトフイ は，ニューギニア地方では剝製にして利用されているほ かは，食べられない“つまらない鳥”と言われているそ うである. 口にしてもまずいようで，「皮は苦く，口唇が 


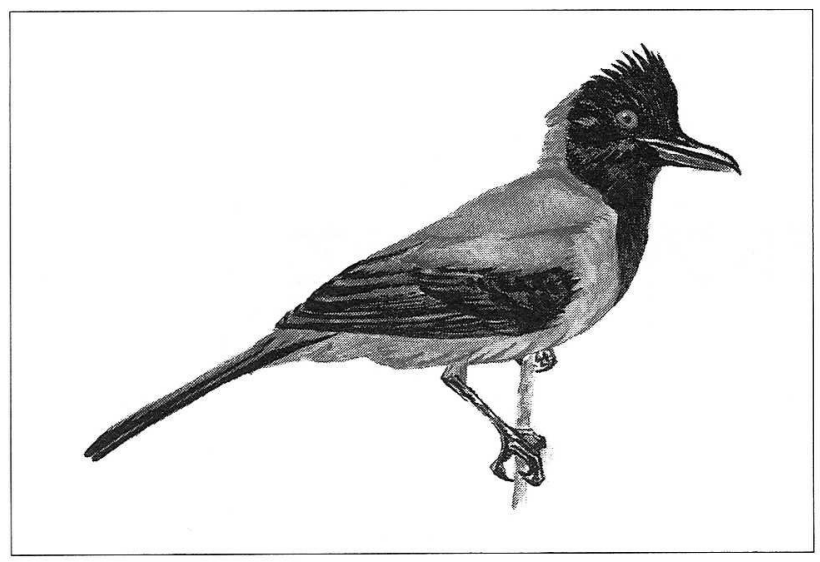

図 1 田フードピトフイ

文献 1 の表紙より, 荒木然一摸写.

ざらつき uncomfortable になる」というから，ひどい渋 柿を食べたような具合であろうか。また，この鳥は酸様 の不快臭が強いという。しかし食性，鳴き声などについ ては記載がない。この鳥の剥製を扱うと, 煩や鼻の感覚 痳痺や灼熱感，くしゃみなどをひき起こすそうである。 これは埃とともに，以下に述べる毒を吸い込むためであ る.

\section{毒の本体は？}

フードピトフイはホモバトラコトキシン homobatrachotoxin（図 2) というステロイド系アルカロイドをも ち, これが毒の本体で, 体重 $65 \mathrm{~g}$ の成鳥では皮膚（重量 にして 4 5 g) 中に 15 20 $\mu \mathrm{g}$, 羽に 2 3 $\mu \mathrm{g}$ ，筋肉その 他を合わせた中に $1 \mu \mathrm{g}$ 以下含まれている。この毒はエ夕 ノールで抽出されるが，毒性は強く，フードピトフイの 皮膚 $10 \mathrm{mg}$ から抽出した毒 $(0.03 \sim 0.05 \mu \mathrm{g})$ でマウスを 10〜20 分で殺す力がある. 毒の量がこれ以下だと，後肢 の㾁痺, 移動困難, 虚脱をきたす。この毒の作用機序は, ナトリウムのイオンチャンネルを阻害し, 神経の働きを 失わせるところにあるとされている。

このピトフイの毒は, 実は幕毒と同じ種類のものなの である。特に，コロンビア毒蛙 Phyllobates のもつステ

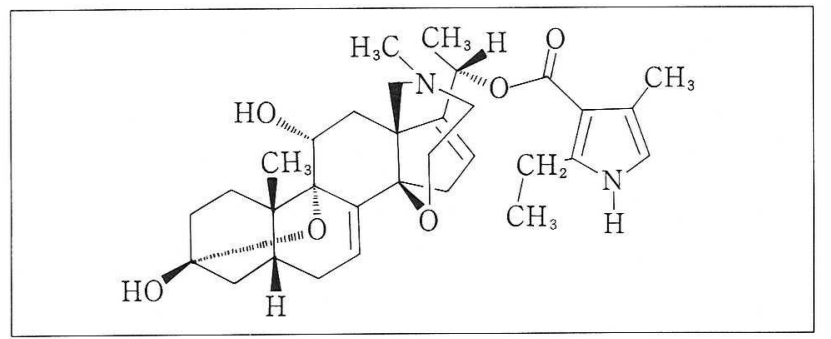

図 2 ロホモパトラコトキシンの化学構造 ${ }^{(1)}$
ロイド系アルカロイドの1つと同じで，この毒蛙の全皮 膚のホモバトラコトキシンの含量はフードピトフイの 10〜20 倍に及び, 現地ではこの毒蛙の皮膚を吹矢の毒と して用いるという。ここで，ピトフイの毒は毒蛙を食べ て蓄積されるのではないかという疑問が生ずるが, 両者 の分布がまったく異なっていて重ならないことから否定 されている(1).

\section{伝説の毒鳥「䲴」とは？}

一方, 中国で古来有名な毒鳥「鶴」とはどんな鳥かと いうと, よく知られているわりには記述が一定せず，過 去の出版物にもいくつか䲴鳥図があるものの, なかなか その像をつかみ難い. 比較的よく利用されている䳋鳥図 を図 3 に示す。集め得た日本および中国の文献から，科 学的に無理がなく, なるべく多くの記事に共通する特徴 を“最もありそうなこと”として組み合わせ，新たな䲮 像を作ってみた。詳細 ${ }^{(3)}$ は省略するが, ほぼ図 3 のよう な黒っぽい大型の鳥の頝 (くび), 喙(くちばし)と足を もっと長くしたような姿になった。これに図鑑風の説明 文をつけてみると次のようになろうか。

「かなり大型（鶁くらい）で全身黒（灰）色，目の辺り と㖨だけが赤い。顼と唄は体に比べて長めで, 顔は䳕型 で目が左右に向いている。肉食性で特に蛇を好み, 鳴き 声は鼓を打つようである。肉は有毒である上になまぐさ くて食用にならない。羽毛に猛毒があり，この毒はアル コールに易溶で，羽毛を酒につけるだけで人を殺すに足 る毒酒が得られる。高いところに巣を作るが, 繁殖力は 弱い. 分布域としては, 中国南部で, 熱帯性の鳥である。 利用法として, 羽は毒薬として, 喙は蛇毒の解毒薬とし て使われた。現在はほとんど絶滅している」。

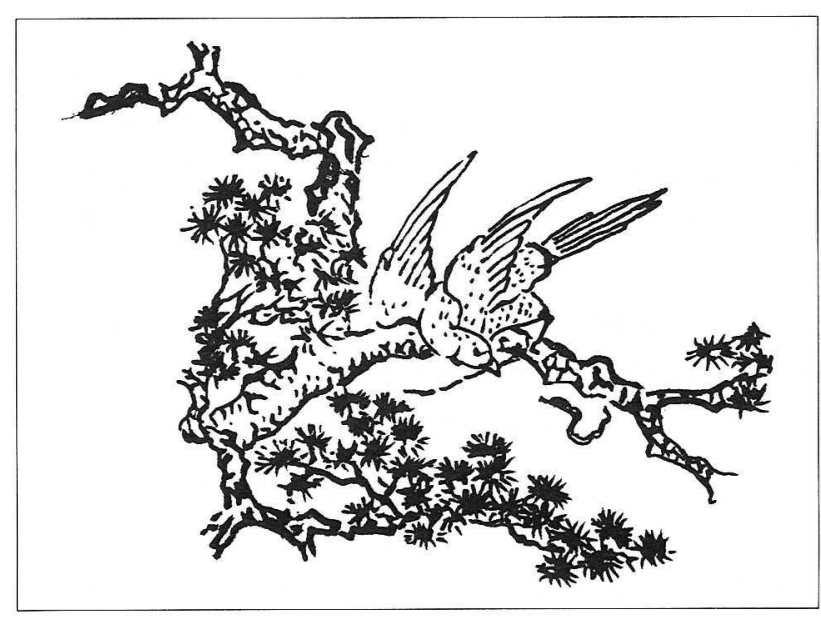

図 3 䲴鳥図

古今図書集成 ${ }^{(2)} よ り$, 荒木然一補筆. 


\section{、䲴の毒はどのようなものだったか}

毒について述べた文献にほぼ共通していることは，䲴 が毒蛇を食べるためにその毒に染まって有毒であり，そ の毒は上述のように希エタノールで容易に抽出されると いうことである．筋肉や血液にも毒があるのではないか という異論もあるが，毒の大部分は羽に含まれていると いうことであろう。

それならば，その毒とはどんなものであろうか。䲴毒 の薬学ないし生化学に関しては，ほとんど手掛かりとな る記事がない．わずかに(1)䳋酒を飲んで「脳裂けて卒す (陸遊『南唐書』)」，(2)毒が手につけば「手爛れ坆つ(『本 草綱目』)」，(3「蛇声口中に入ればすなわち水と為る(『過 庭録』，追は小蛇)」，(4)「蛇口に入ればすなわち爛る(『爾 雅翼』・䲴)」，(5)「五臟に入りて人を爛殺す (『毛気味』)」 という数条があるだけである。これらのうち，(2)（4)は 䲴毒が手や蛇（蛋白質の塊）につくとそれを崩し，溶か してしまうという点で共通している．蛇毒は蛇の唾液腺 から進化した毒腺から分泌されるものなので，したがっ て(2)〜(4)からは蛇毒の蓄積である䲴毒はプロテアーゼ系 消化酵素であってもおかしくはないであろうが，それだ とエタノールに溶けやすいこと，羽毛にプロテアーゼを 有すること，プロテアーゼ系の物質なら消化を受けるは ずであるから毒蛇を食べてその毒を蓄積するなどとは考 え難いこと，唾液の毒と羽の毒を同じと見ていることな どの問題が出てくる. (1)の「脳裂ける」がどんな症状な のか想像できないが，もしロや鼻から血を噴出するとい うような症状であれば，むしろ水銀化合物などの腐食性 の毒が想定されるので，生物の生産する毒とするには少 し無理なようである. (5)はむしろ11)まとめたほうがよ いかとも思われる，結局，文献からはこれ以上，䲴毒の 本態を推定することは困難である.

また，䲴毒の解毒剂として漢方薬の犀角（サイカク） が挙げられている一方で，毒蛇の解毒剤として「䲴の潒 の粉」を使う（『本草綱目集解』）というのは面白いが, 毒蛇の種に対する特異性があるのかどうか，もし鴄の㖨 が入手可能なものならば試してみたいところである。

以上のように，諸文献を通覧すると結局䲴の実在は曖 昧であり，単に伝説に過ぎないようにも思える。しかし 中国人の間では少なくともかつては実在することが信じ られており，有毒か否かは別として，䲴のモデルとなっ た鳥がいたことは確かである，なぜなら，䲴の実見談や 䲴を飼育した話のほか, 䲴は「時制江を過ぎるを得ず(『晋 書石崇伝』)」,つまり当時は䲴を揚子江を越えて北へ持ち 出すことはできないという法律まであったことが何より の証拠となるからである。

\section{・ピトフイは果たして䲴か？}

このように推測される䲴をフードピトフイと比べてみ ると，次のような異同が考えられる。

類似点：(1)羽に毒をもち，その毒は希エタノールに 易溶である. (2)肉に臭気があり食用にはならない. (3)分 布域としては，䲴は南方性の鳥と考えられ，フードピト フイもパプア・ニューギニアなどの熱帯に住む鳥である.

相違点： (1)ピトフイは小鳥であるが䲴は鷲ぐらいの 大型の鳥である. (2)䲴の体色はピトフイのようにけばけ ばしいとは考えられない. (3)毒の含量が両鳥でまったく 異なる，などである．この最後の(3)次のような理由か ら考えられる。

マウスで実験したピトフイの毒の致死量を，体重 60 $\mathrm{kg}$ の人間の場合に換算すると，マウスの体重を約 $30 \mathrm{~g}$ として $0.06 \sim 0.1 \mathrm{mg}$ に相当する.もし，この致死量が正 しいものとすると， $0.1 \mathrm{mg}$ のホモバトラコトキシンは フードピトフイ $5 \sim 6$ 羽分の羽と皮膚に含まれる毒の全 量に相当する．仮に羽だけで毒酒を作るとすると，この 10 倍，すなわち 50 ～ 60 羽分の羽を必要とすることにな る. 盃 1 杯分の酒を約 $100 \mathrm{ml}$ として，この酒に単に羽と 皮膚を浸すだけで濃縮などの操作をせず，これだけの木 モバトラコトキシンを溶かし出すということは，酒のロ スを考えると，フードピトフイの有するホモバトラコト キシン含量ではちょっと無理のように思われる。逆に言 うと，鴄のもつ毒はピトフイに比べてよほど強烈な別種 の毒であるか，同種とすれば含量がよほど高いか，とい うことになるわけである。

このように比べてみると，䲴が実在していたとして， 沜とピトフイとは別種の鳥と考えねばならないであろ う。しかし古代から近代に至るまで，䲴が現代生化学の 方法で分析されたはずはないので，鴄毒が毒蛇由来とい うことにこだわることはないかも知れない，そうすると 「羽毛に毒がありエタノールで抽出可能」という䳋の毒と ピトフイの毒の類似点が生きてくる。つまり，ピトフイ とは別種の䲴という大型の毒鳥がかつては存在してい た，という可能性を否定できなくなるのである.

結論としては，䲴そのものが得られないと明確なこと は言えないということである．初めの目論見とは違った 結果になってしまったが，といって䲴の存在が完全に否 定されたわけでもなく，ちょっと“雪男”(4) 的な感じであ る。それ故，ピトフイのような毒鳥が発見されたという ことは，今は絶滅したがかつては皮膚や羽毛に猛毒をも つ黒っぽい大型の鳥がいたという可能性をかえって強め たのではなかろうか．そうなると，あるモデルになる鳥 
（必ずしも毒をもたなくてよい）が䲴にもあって, 人に忌 まれて早く絶滅し，そのため䲴や，そのモデルになった 鳥の実態が混乱しわからなくなってしまったのではない かとも考えられる。

実際に䳋のモデルを探すつもりで図鑑を開くと，意外 に䲮のモデルになりそうな鳥に出逢うものである.たと えば手近なところで，九官鳥は大きさを別とすれば黒身 黄喙(赤喙ではないが)，南アジアの原産で，おまけに人 語をしゃべって「媒をなす（仲人をする，『離騒』）」こと が可能である，という具合である。あるいはアフリカに はへビクイワシ Sagittarius serpentarius という鳥が いてノネズミやへビを好み，この鳥の肝臟は毒蛇の解毒 薬として使われ, 羽などは呪術に必須であるというから， これは䲴に関する話と同工異曲である。また 120 年ほど 昔に孔雀の肝を飲んで自殺した記録(5) があり，これは毒 鳥の存在についてかなり有力な手掛かりになりそうであ
る. 䲴のような毒鳥の存在も, 必ずしも単に伝説上のこ ととばかりはいえないであろう。

本稿の図の作成に当たり, 比治山短大美術科の荒木然一氏の手を 煩わしたことを記してここに感謝の意を表します。

\section{文献}

1) J.P. Dumbacher, B.M. Beehler, T.F. Spande, H.M. Garraffo \& J.W. Daly : Science, 258, 799 (1992).

2) 日本の文献は, 寺島良安尚順(編): “和漢三才図会”(厚徳社), および小野蘭山，杉本つとむ(編著)：“本草綱目啓蒙”(早稲田 大学出版部)。中国の文献の多くは, “古今図書集成 $51 ”$ (鼎文 書局), 博物彙編，禽虫典，上冊にまとめられている。

3）和泉堯己, 富士川龍郎：“䲴鳥考”, 比治山大学現代文化学部紀 要, No.2, 1995, p. 141

4）周正, 田村達弥(訳)：“中国の野人”, 中公文庫 460 , 中央 公論社, 1991.

5）張 承志：“回教から見た中国”, 中公新書 1128, 中央公論社, 1993, p. 86.

6）“動物の毒の特集”, 化学, 49, No.8, 1994.

\section{お知らせ}

\section{函館工業高等専門学校物質工学科教官公募}

公募人員：助教授または講師 1 名

所属学科と担当教科：物質工学科。環境工学，環境污染分析 法，その他環境関係の実験および講義を担当。

応募資格：年齢 35 歳以下 (着任時)。着任時までに博士の学 位を取得していること．心身ともに健康であこと．高専に おける教育, 研究, 学生生活指導に強い熱意を持っている こと.

採用予定年月日：平成 9 年 4 月 1 日

応募締切: 平成 8 年 8 月 31 日
提出書類：履歴書，研究業績目録（様式は任意）打よび別刷 (主要論文 $: 3$ 編)

問合せ先：干 042 函館市戸倉町 14 番 1 号

函館工業高等専門学校 物質工学科 主任教授 清水 崇

Tel. 0138-57-4271, Fax. 0138-59-4410

応募書類提出先 : $\overline{0} 042$ 函館市戸倉町 14 番 1 号

函館工業高等専門学校 庶務課人事係

選考方法：書類審査と面接（書類審査合格者）

\section{化学と生物}

Vol. 34, No. 7 (392 号)

1996 年 7 月 25 日発行(月刊)

定価 1,030 円(本体 1,000 円)

編集者・社団法人 日本農芸化学会
発行者・株式会社 学会出版センター
113 東京都文京区本郷 $6-2-10$
印刷者・大昭和印刷株式会社
挿 図・伊藤 允三
装 幀・万膳 寛

編集者・社団法人 日本農芸化学会 113 東京都文京区本郷 6-2-10 杉浦 正毅 (田辺製薬(株) 研究開発企画センター) 鈴木 孝仁 (奈良女子大学理学部生物学科)

田付 貞洋 (東京大学農学部生産 - 環境生物学 専攻)

田中 芳一（農林水産省食品総合研究所）

高月昭 (理化学研究所)

中島 泉介 (農林水産省草地試験場)
長野 哲雄 (東京大学薬学部生命薬学専門課程)

仁木 良哉 (北海道大学農学部生物機能化学科)

日向 康吉（東北大学農学部生物生産科学科）

伏谷 伸宏 (東京大学農学部水圈生物科学専攻) 松井 裕 (味の素(株)中央研究所)

水野 猛 (名古屋大学農学部応用生物科学科)

宮下 清貴（農林水産省農業環境技術研究所）

村本 光二 (東北大学農学部応用生物化学科)

室岡義勝（大阪大学工学部応用生物工学科）

山口五十榣 (東京大学農学部応用生命化学専攻)

山本 良郎 (明治乳業(株))

吉原 照彦 (北海道大学農学部生物機能化学科)

米山 忠克 (農林水産省農業研究センター)

\section{企画委員長}

杉本 悦郎 (滋賀県立大学人間文化学部)

\section{企画理事}

大山 莞爾 (京都大学農学部農芸化学科)

高木 正道 (東京大学農学部応用生命工学専攻) 